\title{
KARAKTERISTIK KUE PUKIS DARI PERBANDINGAN MODIFIED CASSAVA FLOUR (MOCAF) DAN PASTA LABU KUNING (Cucurbita moschata Durch)
}

\author{
The Characteristics of 'Pukis'" According to Ratio of \\ Modified Cassava Flour (Mocaf) and Pumpkin Pasta (Cucurbita Moschata Durch)
}

\author{
Ni Kadek Maya Purnamasari ${ }^{1}$, Putu Timur Ina ${ }^{2}$, A.A.I.Sri Wiadnyani ${ }^{2}$ \\ ${ }^{1}$ Mahasiswa Jurusan Imu dan Teknologi Pangan, Fakultas Teknologi Pertanian, Unud \\ ${ }^{2}$ Dosen Jurusan Imu dan Teknologi Pangan, Fakultas Teknologi Pertanian, Unud \\ PS Ilmu dan Teknologi Pangan, Fakultas Teknologi Pertanian, Universitas Udayana, \\ Kampus Bukit Jimbaran, Badung-Bali
}

\begin{abstract}
The purposes of this research were to know the effect of mocaf and pumpkin pasta ratio on the characteristics of pukis and to know the right ratio from mocaf and pumpkin pasta to produce pukis with the best characteristics. The experimental design was used randomized block design with the treatment's factor is ratio of mocaf with pumpkin pasta that is 90\% : 10\%; 80\% : 20\%; 70\%:30\%; 60\%: 40\%; 50\% : 50\%; dan 40\% : $60 \%$. The treatment was repeated as many as 3 repetitions then obtained 18 units. The data obtained were analyzed by variance and if the treatment had an effect on the variable then continued with Duncan test. The results showed that mocaf and pumpkin pasta ratio had significant effect to water content, ash content, total caroten, skoring test (colour, aroma, texture, taste), and hedonic test (colour, aroma, texture, taste, and overall acceptance). Ratio from mocaf and pumpkin pasta (60\%:40\%) is the best characteristic with water content is $57,62 \%$, ash content is $0,84 \%$, total caroten is $2779,97 \mu \mathrm{g} / \mathrm{g}$, color orange and liked, flavor typical pumpkin and liked, texture soft and liked, taste rather typical pumpkin and liked and overall acceptance liked.
\end{abstract}

Keywords: mocaf,pumpkin pasta, 'Pukis', caroten

\section{PENDAHULUAN}

Kue pukis adalah kue basah yang biasanya berbentuk seperti perahu, bagian atasnya berwarna kuning dan lapisan luar bagian bawahnya berwarna kecoklatan, rasanya manis serta mempunyai tekstur yang lembut dan diolah dengan proses pemanggangan. Adonan kue pukis terdiri dari telur, gula pasir, ragi instan, santan, garam, baking powder dan terigu. Salah satu produk pertanian yang menjadi kebutuhan pokok masyarakat Indonesia adalah terigu (Murtiningsih, 2011). Berbagai produk makanan seperti kue pukis umumnya menggunakan terigu sebagai bahan baku.

Terigu mengandung gluten yang tidak semua orang dapat mengkonsumsi dan mencerna gluten dengan baik. Orang yang memiliki alergi terhadap gluten seperti penyandang intoleransi gluten dan autism spectrum disorder (ASD) harus menghindari gluten agar tidak timbul dampak buruk pada tubuh (Yustisia, 2013). Upaya diversifikasi pangan penting dilakukan, selain untuk mengurangi ketergantungan pada terigu, juga untuk menggali potensi pangan lokal sumber karbohidrat (Yanuwardana, 2013).

Umbi-umbian merupakan salah satu sumber karbohidrat dari pangan lokal yang

\footnotetext{
*Korespondensi Penulis:

Email: mayappsari@gmail.com ${ }^{1}$
} 
dapat digunakan sebagai makanan pokok yang bebas gluten, salah satunya adalah singkong. Pengembangan bahan pangan lokal singkong yang dimodifikasi dengan perlakuan fermentasi lalu diolah menjadi tepung, dikenal dengan nama mocaf (Salim, 2011). Mocaf memiliki karakteristik berwarna putih, tidak berbau singkong dan bisa diolah menjadi beragam makanan, contohnya cookies, cake, roti, kue, cake, kue basah dan mie. Keunggulan mocaf yaitu kandungan kalsium yang lebih tinggi dibandingkan dengan gandum serta tidak memiliki kandungan gluten, tetapi kandungan gizinya kurang lengkap sehingga perlu disubstitusi dengan labu kuning yang kaya akan betakaroten.

Labu kuning (Cucurbita moschata) merupakan jenis tanaman sayur-sayuran yang memiliki tingkat produksi relatif tinggi di Indonesia. Menurut Data Badan Pusat Statistik dalam Fatdhilah (2014) menunjukkan hasil rata-rata produksi labu kuning seluruh Indonesia berkisar antara 20-21 ton per hektar sedangkan konsumsi labu kuning di Indonesia masih sangat rendah, yakni kurang dari $50 \mathrm{~kg}$ perkapita pertahun. Harga labu kuning juga cukup terjangkau dan mudah dijumpai di warung, pasar tradisional maupun pasar modern, selain itu labu kuning juga memiliki banyak manfaat yang dapat ditinjau dari kandungan gizinya. Menurut Sudarto (1993), labu kuning merupakan bahan pangan yang kaya $\beta$-karoten atau provitamin $A$, protein, karbohidrat, beberapa mineral seperti kalsium, fosfor, besi serta vitamin B dan C. Labu kuning mengandung karotenoid yang tinggi, hal ini dapat dilihat dari warna daging buah labu kuning. Labu kuning memiliki komposisi gizi yang cukup lengkap, dapat digunakan sebagai sumber antioksidan dan pewarna kuning alami serta mudah didapat dengan harga yang murah (Rahmi et al., 2011).

Labu kuning dapat diolah menjadi pasta untuk dikonsumsi secara langsung maupun digunakan sebagai bahan tambahan atau pensubtitusi dalam pembuatan produk
(Suprapti, 2005). Perbandingan mocaf dan pasta labu kuning dilakukan untuk meningkatkan keanekaragaman pangan dan mengurangi ketergantungan penggunaan terigu sehingga nantinya dapat meningkatkan nilai gizi, sensoris dan ekonomis dari produk. Berdasarkan latar belakang tersebut, maka dilakukan penelitian tentang Karakteristik Kue Pukis dari Perbandingan Modified Cassava Flour (Mocaf) dan Pasta Labu Kuning (Cucurbita moschata Durch).

\section{METODE PENELITIAN}

\section{Bahan dan Alat}

Bahan-bahan yang digunakan dalam penelitian ini terdiri dari labu kuning jenis bokor dalam keadaan segar dan matang yang diperoleh dari pasar tradisional Mengwi, mocaf (merk Ladang Lima), gula pasir lokal, telur, santan, garam, ragi instan (merk Fermipan), dan baking powder yang diperoleh di toko bahan kue UD. Fenny, Denpasar serta bahan kimia yang digunakan dalam melakukan analisis meliputi aquades, etanol, aseton, $\beta$ karoten murni, kloroform, petrolium benzena, dan $\mathrm{Na}_{2} \mathrm{SO}_{4}$.

Alat-alat yang digunakan untuk pembuatan kue pukis adalah waskom, sendok, mixer (Philips), kuas, cetakan kue pukis, kompor gas (Hitachi), panci, termometer, pisau, blender (Philips). Alat yang digunakan untuk analisis fisik dan kimia meliputi lumpang, oven (Memmert), muffle (Daihan), timbangan analitik (Shimadzu), kertas saring Whatman, botol timbang, pipet tetes, spektrofotometer (Thermo Scientific Genesis $10 S$ UV-Vis), kompor listrik, labu Erlenmeyer (Pyrex), gelas beaker (Pyrex), cawan porselin, gelas ukur (Pyrex), pipet volume (Pyrex), pipet mikro (Socorex), pompa karet, labu takar (Pyrex), tabung reaksi (Pyrex), desikator, corong, pinset, labu takar (Pyrex), gelas ukur (Pyrex), vortex (Maxi Mix II Type 367000), penjepit, dan alumunium foil. 


\section{Rancangan Percobaan}

Rancangan percobaan yang dipakai dalam penelitian ini adalah Rancangan Acak Kelompok (RAK) dengan perlakuan perbandingan mocaf dan pasta labu kuning terdiri dari 6 perlakuan yaitu: $(90 \%: 10 \%)$, (80\% : 20\%), (70\% : 30\%), (60\% : 40\%), (50\% :50\%), (40\% : 60\%) yang diulang sebanyak 3 kali, sehingga didapat 18 unit percobaan. Data yang diperoleh dari hasil penelitian dianalisis dengan sidik ragam (ANOVA) melalui program SPSS 21 dan apabila perlakuan berpengaruh terhadap variabel maka dilanjutkan dengan uji Duncan's Multiple Range Test (DMRT) (Gomez dan Gomez, 1995). Perlakuan terbaik diperoleh dari uji objektif dan subjektif kue pukis.

\section{Pelaksanaan Penelitian \\ Proses Pembuatan Pasta Labu Kuning}

Proses pembuatan kue pukis meliputi beberapa tahapan, yaitu (1) pembuatan pasta labu kuning, (2) pembuatan santan, dan (3) pembuatan kue pukis. Labu kuning dikupas, dibuang biji dan jaring-jaring bijinya. Daging buah labu kuning dicuci menggunakan air bersih yang mengalir. Daging buah dipotong dengan ukuran 2 x 5 x $5 \mathrm{~cm}$ kemudian dilakukan pengukusan pada suhu $80^{\circ} \mathrm{C}$ selama 15 menit. Daging buah labu kuning yang sudah matang dihancurkan sampai halus menggunakan blender maka diperoleh pasta labu kuning.

\section{Proses Pembuatan Santan}

Santan dibuat dengan perbandingan kelapa parut dan air (1:2), kemudian dilakukan pemerasan dan penyaringan. Santan kemudian direbus pada suhu $75^{\circ} \mathrm{C}$ selama 30 menit, sambil diaduk agar merata.

\section{Pembuatan Kue Pukis}

Proses pembuatan kue pukis dilakukan dengan cara gula, telur santan, garam, ragi dan baking powder dikocok dengan mixer selama
10 menit. Dimasukkan mocaf dan pasta labu kuning (sesuai perlakuan), diaduk sampai merata. Adonan kemudian ditutup dengan lap kering dan difermentasi selama 3 jam hingga mengembang. Cetakan kue pukis dipanaskan selama 10 menit serta dioleskan margarin hingga merata. Adonan dituang pada cetakan kue pukis pada suhu $95^{\circ} \mathrm{C}$ selama 15 menit, kemudian diangkat dari cetakan.

\section{Variabel yang Diamati}

Variabel yang diamati dalam penelitian ini, diantaranya adalah kadar air dengan metode pengeringan (Sudarmadji et al., 1997), kadar abu dengan metode pengabuan (Sudarmadji et al., 1997), total karoten dengan metode spektrofotometri (Muchtadi, 1989), sifat sensoris menggunakan uji hedonik terhadap warna, aroma, tekstur, rasa, dan penerimaan keseluruhan sedangkan uji skoring dilakukan terhadap warna, aroma, tekstur dan rasa (Soekarto, 1985).

\section{HASIL DAN PEMBAHASAN}

Hasil analisis kadar air, kadar abu dan total karoten dari mocaf dan pasta labu kuning dapat dilihat pada Tabel 1.

Tabel 1. Nilai rata-rata hasil analisis kadar air, kadar abu dan total karoten dari mocaf dan pasta labu kuning

\begin{tabular}{lcc}
\hline \multicolumn{1}{c}{ Komponen } & Mocaf & Pasta Labu Kuning \\
\hline Air $(\%)$ & 12,91 & 86,88 \\
Abu $(\%)$ & 0,38 & 0,79 \\
Total karoten & 0,00 & 33195.38 \\
$(\mu \mathrm{g} / \mathrm{g})$ & & \\
\hline
\end{tabular}

Pasta labu kuning mempunyai kandungan kadar air, kadar abu dan total karoten lebih tinggi dari mocaf yaitu masing-masing $86,88 \% ; 0,79 \% ; 33195,38(\mu \mathrm{g} / \mathrm{g})$. Hasil analisis kadar air, kadar abu, dan total karoten dari kue pukis dapat dilihat pada Tabel 2.

\section{Kadar Air}

Hasil sidik ragam menunjukkan bahwa 
Tabel 2. Nilai rata-rata Kadar Air, Kadar Abu, dan Total Karoten dari Kue Pukis.

\begin{tabular}{lccr}
\hline $\begin{array}{l}\text { Perbandingan } \\
\text { Mocaf } \\
\text { dengan Pasta }\end{array}$ & $\begin{array}{c}\text { Kadar } \\
\text { Air }(\%)\end{array}$ & $\begin{array}{c}\text { Kadar } \\
\text { Abu } \\
\text { Labu Kuning }\end{array}$ & $\begin{array}{c}\text { Total } \\
\text { Karoten } \\
(\mu \mathrm{g} / \mathrm{g})\end{array}$ \\
\hline $90 \%: 10 \%$ & $49,23 \mathrm{~d}$ & $0,63 \mathrm{~d}$ & $988,17 \mathrm{f}$ \\
$80 \%: 20 \%$ & $54,23 \mathrm{c}$ & $0,78 \mathrm{c}$ & $1511,75 \mathrm{e}$ \\
$70 \%: 30 \%$ & $55,63 \mathrm{c}$ & $0,78 \mathrm{bc}$ & $1878,98 \mathrm{~d}$ \\
$60 \%: 40 \%$ & $57,62 \mathrm{~b}$ & $0,84 \mathrm{bc}$ & $2779,97 \mathrm{c}$ \\
$50 \%: 50 \%$ & $59,15 \mathrm{~b}$ & $0,90 \mathrm{~b}$ & $3213,09 \mathrm{~b}$ \\
$40 \%: 60 \%$ & $61,28 \mathrm{a}$ & $1,17 \mathrm{a}$ & $4067,27 \mathrm{a}$ \\
\hline
\end{tabular}

Keterangan : Nilai rata - rata yang diikuti oleh huruf yang berbeda pada kolom yang sama menunjukkan berbeda nyata pada $\mathrm{Uji}$ Duncan $(\mathrm{P}<0,05)$.

perbandingan mocaf dengan pasta labu kuning berpengaruh sangat nyata $(\mathrm{P}<0,01)$ terhadap kadar air kue pukis. Tabel 2 menunjukkan kadar air terendah diperoleh dari perlakuan 90\% : 10\% yaitu 49,23\% sedangkan kue pukis dengan kadar air tertinggi diperoleh dari perlakuan $40 \%$ : $60 \%$ yaitu $61,28 \%$.

Peningkatan kadar air kue pukis disebabkan oleh bertambahnya konsentrasi pasta labu kuning, semakin banyak penambahan pasta labu kuning semakin tinggi kadar air kue pukis. Hal ini disebabkan oleh pasta labu kuning memiliki kadar air yang lebih besar dibandingkan mocaf. Berdasarkan hasil analisis bahan baku, kandungan kadar air pasta labu kuning lebih tinggi yaitu sebesar kue pukis $86,88 \%$ dibandingkan dengan mocaf yaitu sebesar 12,91\% (Tabel 1).

\section{Kadar Abu}

Hasil sidik ragam menunjukkan bahwa perbandingan mocaf dengan pasta labu kuning berpengaruh sangat nyata $(\mathrm{P}<0,01)$ terhadap kadar abu kue pukis.Tabel 2 menunjukkan kadar abu kue pukis terendah diperoleh dari perlakuan $90 \%$ : $10 \%$ yaitu $0,63 \%$, sedangkan kadar abu tertinggi kue pukis diperoleh dari perlakuan 40\% : 60\% yaitu $1,17 \%$. Kadar abu kue pukis tinggi pada perlakuan P6 seiring dengan tingginya konsentrasi pasta labu kuning, hal tersebut disebabkan karena tingginya kandungan mineral yang terdapat pada pasta labu kuning. Hal ini dikarenakan pasta labu kuning mengandung mineral lebih tinggi dibandingkan dengan mocaf sehingga jumlahnya semakin besar seiring dengan penambahan pasta labu kuning. Berdasarkan hasil analisis bahan baku kadar abu pasta labu kuning yaitu $0,79 \%$ lebih besar dari pada kadar abu mocaf yaitu $0,38 \%$ (Tabel 1). Kandungan mineral dalam labu kuning adalah kalsium(45,00 $\mathrm{mg} / 100 \mathrm{~g}), \quad$ fosfor $(64,00 \mathrm{mg} / 100 \mathrm{~g})$ dan besi $(1,40 \mathrm{mg} / 100 \mathrm{~g})$ (Hendrasty, 2003). Mineral berfungsi sebagai zat pembangun dan pengatur di dalam tubuh. Beberapa fungsi mineral dalam tubuh diantaranya kalsium berperan dalam membentuk tulang dan gigi serta mengatur proses biologis, fosfor berperan dalam penyimpanan dan pengeluaran energi (Winarno, 2002).

\section{Total Karoten}

Hasil sidik ragam menunjukkan bahwa perbandingan mocaf dengan pasta labu kuning berpengaruh sangat nyata $(\mathrm{P}<0,01)$ terhadap total karoten kue pukis. Tabel 2 menunjukkan total karoten terendah kue pukis diperoleh dari perlakuan $90 \%$ : $10 \%$ yaitu $988.17 \mu \mathrm{g} / \mathrm{g}$ sedangkan total karoten tertinggi kue pukis diperoleh dari perlakuan $40 \%$ : $60 \%$ yaitu $4067.27 \mu \mathrm{g} / \mathrm{g}$.

Total karoten kue pukis bertambah seiring dengan tingginya konsentrasi penambahan pasta labu kuning. Berdasarkan hasil analisis bahan baku total karoten pasta labu kuning yaitu $33195,38 \mu \mathrm{g} / \mathrm{g}$ lebih besar dari pada total karoten mocaf yaitu $0,00 \mu \mathrm{g} / \mathrm{g}$ (Tabel 1). Beta karoten merupakan sumber terbaik vitamin A yang diperlukan untuk meningkatkan kesehatan mata dan kulit. 


\section{Evaluasi Sifat Sensoris}

Evaluasi sifat sensoris kue pukis dilakukan dengan uji hedonik (warna, aroma, tekstur, rasa dan penerimaan keseluruhan) dan uji skoring ( warna, aroma, tekstur, dan rasa). Nilai rata-rata uji hedonik terhadap warna, aroma, tekstur, rasa dan penerimaan keseluruhan kue pukis dapat dilihat pada Tabel 3. Nilai rata-rata uji skoring terhadap warna, aroma, tekstur, dan rasa dapat dilihat pada pada Tabel 4.

Tabel 3. Nilai rata-rata Uji Hedonik Warna, Aroma, Tekstur, Rasa dan Penerimaan Keseluruhan Kue Pukis

\begin{tabular}{|c|c|c|c|c|c|}
\hline \multirow{2}{*}{$\begin{array}{c}\text { PerbandinganMocaf } \\
\text { dengan Pasta Labu Kuning }\end{array}$} & \multicolumn{5}{|c|}{ Nilai rata - rata uji hedonik } \\
\hline & Warna & Aroma & Tekstur & Rasa & $\begin{array}{l}\text { Penerimaan } \\
\text { Keseluruhan }\end{array}$ \\
\hline $90 \%: 10 \%$ & $4,35 \mathrm{c}$ & $4,70 \mathrm{c}$ & $5,55 \mathrm{~b}$ & $5,05 \mathrm{c}$ & $5,30 \mathrm{c}$ \\
\hline $80 \%: 20 \%$ & $4,60 \mathrm{c}$ & $4,70 \mathrm{c}$ & $5,60 \mathrm{~b}$ & $5,15 \mathrm{c}$ & $5,35 \mathrm{c}$ \\
\hline $70 \%: 30 \%$ & $5,35 \mathrm{~b}$ & $5,35 \mathrm{~b}$ & $5,70 \mathrm{ab}$ & $5,90 \mathrm{ab}$ & $5,80 \mathrm{ab}$ \\
\hline $60 \%: 40 \%$ & $6,15 \mathrm{a}$ & $6,00 \mathrm{a}$ & $6,05 \mathrm{a}$ & $5,95 \mathrm{a}$ & $5,90 \mathrm{a}$ \\
\hline $50 \%: 50 \%$ & $5,50 \mathrm{~b}$ & $5,90 \mathrm{a}$ & $6,00 \mathrm{a}$ & $5,70 \mathrm{ab}$ & $5,75 \mathrm{ab}$ \\
\hline $40 \%: 60 \%$ & $5,25 \mathrm{~b}$ & $4,75 \mathrm{c}$ & $5,20 \mathrm{c}$ & $5,40 \mathrm{bc}$ & $5,50 \mathrm{bc}$ \\
\hline
\end{tabular}

Keterangan : Nilai rata - rata yang diikuti oleh huruf yang berbeda pada kolom yang sama menunjukkan berbeda nyata pada Uji Duncan $(\mathrm{P}<0,05)$.

Kriteria hedonik : 1 (sangat tidak suka), 2 (tidak suka), 3 (agak tidak suka), 4 (biasa), 5 (agak suka), 6 (suka), 7 (sangat suka).

Tabel 4. Nilai rata-rata Uji Skoring Warna, Aroma, Tekstur, dan Rasa Kue Pukis

\begin{tabular}{ccccc}
\hline \multirow{2}{*}{$\begin{array}{c}\text { Perbandingan } \\
\text { Mocaf }\end{array}$} & \multicolumn{3}{c}{ Nilai rata - rata uji skoring } \\
\cline { 2 - 5 } dengan Pasta Labu Kuning & Warna & Aroma & Tekstur & Rasa \\
\hline $90 \%: 10 \%$ (P1) & $1,15 \mathrm{f}$ & $2,55 \mathrm{c}$ & $4,30 \mathrm{a}$ & $2.55 \mathrm{c}$ \\
$80 \%: 20 \%(\mathrm{P} 2)$ & $1,90 \mathrm{e}$ & $2,60 \mathrm{c}$ & $4,35 \mathrm{a}$ & $2.60 \mathrm{c}$ \\
$70 \%: 30 \%$ (P3) & $2,45 \mathrm{~d}$ & $3,25 \mathrm{~b}$ & $4,40 \mathrm{a}$ & $3.25 \mathrm{~b}$ \\
$60 \%: 40 \%(\mathrm{P} 4)$ & $3,55 \mathrm{c}$ & $4,05 \mathrm{a}$ & $4,20 \mathrm{a}$ & $3.70 \mathrm{a}$ \\
$50 \%: 50 \%$ (P5) & $4,05 \mathrm{~b}$ & $3,70 \mathrm{a}$ & $3,60 \mathrm{~b}$ & $3.85 \mathrm{a}$ \\
$40 \%: 60 \%$ (P6) & $4,65 \mathrm{a}$ & $3,65 \mathrm{a}$ & $3.50 \mathrm{~b}$ & $\mathrm{~m}$
\end{tabular}

Keterangan : Nilai rata - rata yang diikuti oleh huruf yang berbeda pada kolom yang sama menunjukkan berbeda nyata pada Uji Duncan 0,05 .

Kriteria warna $\quad: 1$ (kuning), 2 (agak oranye muda), 3 (oranye muda), 4 (oranye), 5 (sangat oranye).

Kriteria aroma : 1 (tidak khas labu kuning), 2 (kurang khas labu kuning), 3 (agak khas labu kuning), 4 (khas labu kuning), 5 (sangat khas labu kuning).

Kriteria tekstur : 1 (tidak empuk), 2 (agak tidak empuk), 3 (agak empuk), 4 (empuk), 5 (sangat empuk).

Kriteria rasa $\quad: 1$ (tidak khas labu kuning), 2 (kurang khas labu kuning), 3 (agak khas labu kuning), 4 (khas labu kuning), 5 (sangat khas labu kuning).

\section{Warna}

Hasil sidik ragam menunjukkan bahwa perbandingan pasta labu kuning dengan mocaf berpengaruh sangat nyata $(\mathrm{P}<0,01)$ terhadap warna kue pukis (uji hedonik). Tabel 3 menunjukkan bahwa nilai tertinggi tingkat kesukaan panelis terhadap warna kue pukis diperoleh dari perlakuan $60 \%: 40 \%$ yaitu 6,15 (suka) sedangkan nilai kesukaaan terendah diperoleh dari perlakuan $90 \%: 10 \%$ yaitu 4,35 (biasa) serta tidak berbeda dengan P2. Perbandingan pasta labu kuning dengan mocaf berpengaruh sangat nyata $(\mathrm{P}<0,01)$ terhadap warna (uji skoring) kue pukis. Tabel 4 menunjukkan bahwa nilai rata-rata penerimaan terhadap warna uji skoring kue pukis tertinggi 
diperoleh dari perlakuan $40 \%: 60 \%$ yaitu 4,65 (sangat oranye) dan terendah diperoleh dari perlakuan 90\%: 10\% yaitu 1,15 (kuning).

Menurut Winarno (2002) warna merupakan komponen yang penting untuk menentukan kualitas atau derajat penerimaan suatu bahan pangan. Suatu bahan pangan meskipun dinilai enak dan teksturnya sangat baik, tetapi memiliki warna yang tidak menarik atau memberi kesan telah menyimpang dari warna yang seharusnya maka bahan tersebut tidak akan dikonsumsi. Penentuan mutu suatu bahan pangan pada umumnya tergantung pada warna karena warna tampil terlebih dahulu.

Dari hasil sidik ragam diketahui bahwa panelis lebih menyukai kue pukis dengan perlakuan $60 \%: 40 \%$ yang berwarna oranye daripada yang berwarna kuning, hal ini disebabkan karena penambahan pasta labu kuning lebih menarik minat panelis. Hal ini disebabkan warna pada pasta labu kuning yang dominan berwarna kuning-jingga sehingga mempengaruhi warna produk akhir makanan.

Panelis menyukai kue pukis dengan perlakuan $60 \%$ : $40 \%$ yang berwarna oranye. Hal ini disebabkan warna pada pasta labu kuning sehingga mempengaruhi warna produk akhir makanan. Menurut Winarno (2002) warna merupakan komponen yang penting untuk menentukan kualitas atau derajat penerimaan suatu bahan pangan. Suatu bahan pangan meskipun dinilai enak dan teksturnya sangat baik, tetapi memiliki warna yang tidak menarik atau memberi kesan telah menyimpang dari warna yang seharusnya maka bahan tersebut tidak akan dikonsumsi. Penentuan mutu suatu bahan pangan pada umumnya tergantung pada warna karena warna tampil terlebih dahulu.

\section{Aroma}

Hasil sidik ragam menunjukkan bahwa perbandingan pasta labu kuning dengan mocaf berpengaruh sangat nyata $(\mathrm{P}<0,01)$ terhadap aroma kue pukis. Tabel 3 menunjukkan bahwa nilai tertinggi tingkat kesukaan panelis terhadap aroma kue pukis diperoleh dari perlakuan $60 \%: 40 \%$ yaitu 6,00 (suka) serta tidak berbeda dengan perlakuan 50\% : 50\% sedangkan nilai kesukaaan terendah diperoleh dari perlakuan $90 \%: 10 \%$ dan $80 \%: 20 \%$ yaitu 4,70 (agak suka). Perbandingan pasta labu kuning dengan mocaf berpengaruh sangat nyata $(\mathrm{P}<0,01)$ terhadap aroma (uji skoring) kue pukis. Tabel 4 menunjukkan bahwa nilai rata-rata penerimaan terhadap aroma uji skoring kue pukis tertinggi diperoleh dari perlakuan 60\% : 40\% yaitu 4,05 (khas labu kuning), tidak berbeda dengan perlakuan $50 \%$ : 50\% dan 40\% : $60 \%$ serta terendah diperoleh dari perlakuan 40\%: 60\% yaitu 2,55 (agak khas labu kuning).

Panelis menyukai kue pukis dengan perlakuan $60 \%$ : $40 \%$ yang beraroma khas labu kuning. Hal ini disebabkan karena semakin tinggi konsentrasi pasta labu kuning sehingga aroma labu kuning pada kue pukis semakin kuat yang mempengaruhi aroma kue pukis. Menurut Meilgaard, et al. (2000) menyatakan bahwa aroma makanan timbul disebabkan oleh terbentuknya senyawa volatil yang mudah menguap, selain itu proses pemasakan yang berbeda akan menimbulkan aroma yang berbeda.

\section{Tekstur}

Hasil sidik ragam menunjukkan bahwa perbandingan pasta labu kuning dengan mocaf berpengaruh sangat nyata $(\mathrm{P}<0,01)$ terhadap tekstur kue pukis (uji hedonik). Tabel 3 menunjukkan bahwa nilai tertinggi tingkat kesukaan panelis terhadap tekstur kue pukis diperoleh dari perlakuan $60 \%: 40 \%$ yaitu 6,05 (suka) serta tidak berbeda dengan perlakuan 70\% : 30\% dan 50\% : 50\% sedangkan nilai kesukaan terendah diperoleh dari perlakuan $40 \%$ : $60 \%$ yaitu 5,20 (agak suka). Perbandingan pasta labu kuning dengan mocaf berpengaruh sangat nyata $(\mathrm{P}<0,01)$ terhadap tekstur (uji skoring) kue pukis. Tabel 4 menunjukkan bahwa nilai penerimaan terhadap tekstur uji skoring kue pukis tertinggi 
diperoleh dari perlakuan P3 yaitu 4,40 (empuk), sedangkan nilai terendah diperoleh dari perlakuan 40\%: 60\% yaitu 3,50 (agak empuk).

Karakteristik tekstur kue pukis yang empuk berasal dari penggunaan mocaf. Pati yang terkandung dalam mocaf lebih besar sehingga terjadi proses gelatinasi yang menghasilkan tekstur empuk. Menurut Subagio (2009), kue pukis yang berasal dari mocaf dan puree wortel menghasilkan kue pukis dengan tekstur empuk. Panelis menyukai kue pukis dengan perlakuan $60 \%$ : 40\% yang memiliki tekstur empuk.

\section{Rasa}

Hasil sidik ragam menunjukkan bahwa perbandingan pasta labu kuning dengan mocaf berpengaruh sangat nyata $(\mathrm{P}<0,01)$ terhadap rasa kue pukis. Tabel 3 menunjukkan bahwa nilai tertinggi tingkat kesukaan panelis terhadap rasa kue pukis diperoleh dari perlakuan $60 \%$ : 40\% yaitu 5,95 (suka) dan tidak berbeda dengan perlakuan $70 \%: 30 \%$ serta 50\% : 50\% sedangkan nilai kesukaaan terendah diperoleh dari perlakuan 90\%: 10\% yaitu 5,05 ( agak suka). Perbandingan pasta labu kuning dengan mocaf berpengaruh sangat nyata $(\mathrm{P}<0,01)$ terhadap rasa (uji skoring) kue pukis. Tabel 4 menunjukkan bahwa nilai ratarata penerimaan terhadap rasa uji skoring kue pukis tertinggi diperoleh dari perlakuan $40 \%$ : $60 \%$ yaitu 3,85 (khas labu kuning) serta tidak berbeda dengan 50\%: 50\% dan terendah diperoleh dari perlakuan $90 \%: 10 \%$ yaitu 2,55 (agak khas labu kuning). Panelis menyukai kue pukis dengan perlakuan $60 \%$ : $40 \%$ dengan rasa khas labu kuning.

Hal ini disebabkan karena tingginya konsentrasi pasta labu kuning sehingga dihasilkan kue pukis dengan rasa khas labu kuning kuat. Menurut Khasanah (2003) menyatakan bahwa rasa adalah faktor yang dinilai panelis setelah tekstur, warna dan aroma yang dapat yang mempengaruhi penerimaan produk pangan. Rasa timbul akibat adanya rangsangan kimiawi yang dapat diterima oleh indera pencicip atau lidah. Rasa yang enak dapat menarik perhatian sehingga konsumen lebih cenderung menyukai makanan dari rasanya. Jika komponen aroma, warna dan tekstur baik tetapi konsumen tidak menyukai rasanya maka konsumen tidak akan menerima produk pangan tersebut.

\section{Penerimaan Keseluruhan}

Hasil sidik ragam menunjukkan bahwa perbandingan pasta labu kuning dengan mocaf berpengaruh sangat nyata $(\mathrm{P}<0,01)$ terhadap penerimaan keseluruhan kue pukis. Tabel 3 menunjukkan bahwa nilai rata-rata tingkat kesukaan panelis terhadap penerimaan keseluruhan kue pukis diperoleh dari perlakuan $60 \%$ : 40\% yaitu 5,90 (suka) dan tidak berbeda dengan perlakuan $70 \%: 30 \%$ dan 50\% : 50\% sedangkan nilai kesukaan terendah diperoleh dari perlakuan 40\%: $60 \%$ yaitu 5,30 (agak suka) dan tidak berbeda dengan perlakuan $80 \%: 20 \%$ serta $40 \%: 60 \%$. Penerimaan keseluruhan kue pukis dipengaruhi oleh beberapa faktor seperti warna, aroma, tekstur dan rasa.

\section{SIMPULAN DAN SARAN}

\section{Simpulan}

1. Perbandingan pasta labu kuning dengan mocaf berpengaruh terhadap kadar air, kadar abu, total karoten, uji skoring (warna, aroma, tekstur, rasa) dan uji hedonik (warna, aroma, tekstur, rasa dan penerimaan keseluruhan) kue pukis.

2. Perbandingan mocaf dan pasta labu kuning $(60 \%: 40 \%)$ merupakan karakteristik terbaik kue pukis dengan kriteria kadar air 57,62\%; kadar abu $0,84 \%$; total karoten $2779,97 \mu \mathrm{g} / \mathrm{g}$, warna oranye dan suka, aroma khas labu kuning dan suka, tekstur empuk dan suka rasa agak khas labu kuning dan suka serta penerimaan keseluruhan suka. 


\section{Saran}

Berdasarkan hasil penelitian untuk menghasilkan kue pukis terbaik disarankan menggunakan perbandingan mocaf dan pasta labu kuning (60\%: 40\%).

\section{DAFTAR PUSTAKA}

Fatdhilah, N. 2014. Pengaruh Jumlah Maltodekstrin Dan Lama Pengeringan Terhadap Sifat Organoleptik Sup Labu Kuning Instan. Skripsi PKK FT-UNESA Surabaya.

Gomez, K. A. dan A. A. Gomez. 1995. Prosedur Statistik Untuk Penelitian Pertanian. UI Press. Jakarta.

Hendrasty, H. K. 2003. Tepung Labu Kuning Pembuatan dan Pemanfaatannya. Karnisius, Yogyakarta.

Khasanah, U. 2003. Formulasi Karakterisasi Fisiko-Kimia dan Organoleptik Produk Makanan Sarapan Ubi Jalar (Sweet Potato Flakes). Skripsi. Fakultas Teknologi Pertanian. Institut Pertanian Bogor. Bogor.

Meilgaard, M., G. V. Civille and B. T. Carr. 2000. Sensory Evaluation Techniques. Boca Raton, Florida : CRC Press.

Muchtadi, T. 1989. Teknologi Proses PengolahanPangan. Direktorat Jenderal Pendidikan Tinggi.Pusat Antar Universitas Pangan dan GiziInstitut Pertanian Bogor, Bogor.

Murtiningsih, S. 2011. Membuat Tepung Umbi dan Variasi Olahannya. Agromedia Pustaka, Jakarta.

Rahmi, S.L., A. Indriyani., dan L. Surhaini. 2011. Penggunaan BuahLabuKuning sebagai SumberAntioksidan dan PewarnaAlami pada Produk MieBasah. Fakultas Pertanian, Universitas Jambi. Vol.
13. (2) : 29-36.

Salim, E. 2011. Mengolah Singkong Menjadi tepung Mocaf Bisnis Produk Alternatif Pengganti Terigu. Yogyakarta: Lily Publisher.

Soekarto, S. T. 1985. Penilaian Organoleptik untuk Industri Pangan dan Hasil Pertanian.Jakarta : Bhratara Karya Aksara

Subagio, A. 2009. Modified Cassava Flour Sebuah Masa Depan Ketahanan Pangan Nasional Berbasis Potensi Lokal. Fakultas Teknologi Pertanian Universitas Jember.

Sudarmadji, S., B. Haryono, dan Suhardi. 1997. Prosedur Analisa Bahan Makanan Dan Pertanian. Liberty. Yogyakarta.

Sudarto, Y. 1993. Budidaya Waluh. Kanisius, Yogyakarta.

Suprapti, L. 2005. Selai dan Cake Waluh. Kanisius. Yogyakarta.

Winarno, F. G. 2002. Kimia Pangan dan Gizi. PT. Gramedia, Jakarta.

Yanuwardana. 2013. Kajian Karakteristik Fisikokimia Tepung Labu Kuning (Cucurbita moschata, Durch) Termodifikasi dengan Variasi Lama Perendaman dan Konsentrasi Asam Laktat. Skripsi Universitas Sebelas Maret. Surakarta.

Yustisia, R. 2013. Pengaruh Penambahan Telur Terhadap Kadar Protein, Serat, Tingkat Kekenyalan dan Penerimaan Mie Basah Bebas Gluten Berbahan Baku Tepung Komposit.Journal of Nutrition College, 2 (4): 697-703. 